\title{
DA SEMIOSFERA À LUDUSFERA: POR UMA FILOSOFIA DO JOGO DE LINGUAGEM NA HIPERMÍDIA
}

\author{
SEMIOSPHERE OF THE LUDUSFERA: A PHILOSOPHY OF LANGUAGE GAME IN \\ HYPERMEDIA
}

SEMIOSFERA DEL LUDUSFERA: UNA FILOSOFÍA DE JUEGO DE LENGUAJE EN

HIPERMEDIA

\author{
Dóris Sathler de Souza Larizzatti \\ Doutoranda em Ciências da Comunicação \\ PPGCOM ECA USP \\ dorislarizzatti@gmail.com
}

\section{Resumo}

O objetivo geral deste artigo é pontuar aspectos dos conceitos de espaço semiótico e semiosfera: sua história e filiações filosóficas, ideológicas e pragmáticas, com destaque ao pensamento de Lotman e de seus interlocutores, que preconizam uma semiótica que estuda a cultura como uma metalinguagem espacial. E, especificamente, visa colaborar para o embasamento filosófico-teórico do metaconceito de Ludusfera, em que comunicaremos a filosofia do jogo de linguagem na hipermídia, a partir de contribuições temáticas interdisciplinares, apresentando alguns nexos teóricos consequentes e não conclusivos, mas frutos de uma reflexão sistemática sobre o processo em causa.

Palavras-chave: Semiosfera. Ludusfera. Hipermídia.

\begin{abstract}
The objective of this paper is to score aspects of the concepts of space and semiosphere semiotic: its history and affiliations, philosophical, ideological and pragmatic, especially the thought of Lotman and his interlocutors, who advocate a semiotics studies the culture as a meta-space. And specifically, aims to contribute to the philosophical and theoretical foundation of the meta-concept of ludusfera, communicating the philosophy of language game in hypermedia, from interdisciplinary thematic contributions, with some resulting theoretical connections and not conclusive, but the fruit of a reflection systematic about the process in question.
\end{abstract}

Keywords: Semiosphere. Ludusfera. Hypermedia.

\section{Resumen}

El objetivo de este trabajo es anotar los aspectos de los conceptos de espacio y semiosfera semióticos: su historia y afiliaciones filosóficas, ideológicas y pragmáticas, especialmente la idea de Lotman y sus interlocutores, que abogan por una semiótica que estudian la cultura como un espacio metalenguaje. Y tiene como objetivo específico de contribuir a la base filosófica y teórica del concepto de meta-ludusfera, que comunican la filosofía de juego de 
lenguaje en hipermedia, las contribuciones de temática interdisciplinaria, presentando algún nexo teórico emergente y no es concluyente, sino el fruto de una reflexión sistemática sobre el proceso en cuestión.

Palabras clave: Semiosfera. Ludusfera. Hipermedia

\section{INTRODUÇÃO}

Abordar conceitos de espaço semiótico e semiosfera, envolvendo sua história e filiações filosóficas, ideológicas e pragmáticas, com destaque ao pensamento de Lotman e de seus interlocutores, que preconizam uma semiótica que estuda a cultura como uma metalinguagem espacial. E, especificamente, colaborar para o embasamento filosófico-teórico do metaconceito de Ludusfera, em que comunicaremos a filosofia do jogo de linguagem na hipermídia, a partir de contribuições temáticas interdisciplinares.

\section{DESENVOLVIMENTO}

A partir de autores imersos no mundo com abordagens interdisciplinares, necessárias à construção tridimensional da hipermídia, como filosofia, teoria e metodologia, propomos o metaconceito de Ludusfera como uma exomatização de expressividades digitais, originária do campo da Semiosfera, por meio da circularidade da compreensão da fenomenologia hermenêutica de Gadamer e Heidegger.

\subsection{Semiosfera e sua origem}

De acordo com Henn (2010), desde a década de 1980, Iuri Lotman (1922-1993) esboçava intrigantes apreciações sobre as relações entre arte, ciência e técnica. O semioticista russo ironizava o temor, bastante explorado pela ficção científica, de que as máquinas dominassem a espécie humana e sugeria que esse sentimento embotava a percepção mais precisa das reais implicações da produção artística na própria técnica, aspecto que, no seu entendimento, fazia travar não só o desenvolvimento técnico, mas também a evolução geral da cultura. Por conta disso, no imbricamento dessas relações, a questão não estava no tradicional interesse pelo impacto da técnica sobre a arte, mas exatamente no contrário. “A influência da arte sobre a técnica é bem mais substancial”, precisava Lotman (LOTMAN; USPENSKIJ, 1981, pp. 27-30), em uma linha de argumentação que reflete o aspecto sistêmico do seu pensamento semiótico e que o coloca em sintonia com perspectivas contemporâneas.

Lembra o autor que, durante muito tempo, o pensamento técnico-científico orientou-se na ideia de que o mundo da natureza estava organizado de maneira ineficaz e deveria ser 
aperfeiçoado pela racionalização sobre a qual teríamos domínio. Entretanto, a ciência da vida, sobretudo na segunda metade do século $\mathrm{XX}$, veio nos mostrar exatamente o contrário: o mundo da natureza é um mecanismo tão complexo e racional que estamos ainda muito aquém de compreendê-lo em toda a sua extensão (HENN, 2010). "Pode-se afirmar com certeza que uma obra de arte é o que existe de mais complexo e de funcionamento mais eficaz entre todas as coisas que o homem criou até o momento”. Além de pontuar a difícil explicação da existência em uma sociedade sem arte, percebia na obra artística o protótipo ideal da máquina do futuro acreditando que "tendo assimilado certos princípios estruturais da obra de arte, o futuro objeto técnico não a substituirá e não se lhe identificará; pelo contrário, será então que a oposição funcional entre arte e técnica aparecerá em estado puro” (LOTMAN; USPENSKIJ, 1981, p. 29).

Mais tarde, segundo Machado (2007a), semiosfera, concepção de cultura como espaço semiótico, foi conceitualmente formulada por Lotman, em artigo homônimo de 1984, para designar o habitat e a vida dos signos no universo cultural, ou seja, a totalidade da cultura está imersa em um espaço semiótico, descontínuo, cujos temas só podem funcionar por meio da interação com esse espaço (LOTMAN; USPENSKIJ, 1981). Este conceito derivou de outro anterior: biosfera, originalmente definido pelo biogeoquímico russo-ucraniano Vladimir Ivanovich Vernadski (1997), que viveu de 1863 a1945, como a película que visa à conservação da matéria viva, por meio da transformação da energia radiante do sol em energia química e física.

Henn (2010) destaca que Vernadski também imaginou a possibilidade de um terceiro estágio da evolução do planeta, considerando-se a geosfera como primeiro e a biosfera como segundo, a saber: a noosfera - o mundo formado pelo pensamento ou pelas ideias humanas. Conforme Mortier (1981), tal conceito também foi desenvolvido na primeira metade do século XX pelo filósofo jesuíta francês Teilhard de Chardin, que inseriu na constituição da noosfera, os processos tecnológicos. Diversas apropriações da concepção de noosfera estabeleceram-se ao longo da segunda metade do século passado e tal formulação também não escapou a Mikhail Bakhtin (LOTMAN; USPENSKIJ, 2003, p. 372), cuja vida data de 1895 a 1975, pois,

com o surgimento da consciência no mundo (na existência) e, talvez, com o surgimento da vida biológica (é possível que não só os animais como também as árvores e a relva testemunhem e julguem) o mundo (a existência) muda radicalmente. (...) Porque pela primeira vez aparecem na cena da existência terrestre as personagens novas e principais do acontecimento - a testemunha e o juiz. 
Lotman propôs um novo nome para esse ambiente, no qual a cultura se institui: a semiosfera, cujo funcionamento tem similitude com a biosfera. E mais: o termo dota o ambiente de materialidade, de concretude, na medida em que a cultura se manifesta em textos ou sistemas de signos, cujo processamento só é possível nesse espaço semiótico específico (HENN, 2010). Ou seja, a semiosfera é o espaço das semioses e de todas as dinâmicas inclusas, até mesmo as de tensionamento que serão trabalhadas posteriormente em Cultura $e$ explosão (LOTMAN, 1999). Ao trilhar o caminho já consolidado por Bakhtin, em seus estudos sobre o dialogismo textual e o cronotropo, o semioticista investiu na compreensão da dinâmica dos encontros entre diferentes culturas, ou seja, como se encontram, que tipo de diálogo travam entre si e como criam experiências capazes (explosivas) de reconfigurar o campo das forças culturais em todos os níveis da conjuntura social, visando a construção de uma teoria crítica cultural.

\subsection{Semiosfera e outras esferas teóricas}

A teoria da semiosfera nos ajuda a refletir sobre os mecanismos básicos da constituição do espaço semiótico, tais como irregularidade, heterogeneidade, fronteira e transformação da informação em texto e, particularmente, o hibridismo - características fundamentais da cultura contemporânea, povoada de semiodiversidade (RISÉRIO, 2002), fértil e exuberante, contrariamente ao conceito originário do campo da biologia, com exemplos em mitos, religiões, artes, arquitetura, filmes, lazer, poesia, dança, línguas, ciência, tecnologias, expressividades digitais, jogos, entre outras sistematizações por se fazer.

Merrel (2003, p. 165) também estabelece uma conseqüente releitura sobre a natureza da "biossemiosfera fluindo triadicamente", marcada pela heterogeneidade, sendo esta definida tanto pela diversidade de elementos quanto pelas suas diferentes funções (LOTMAN, 1990). Isto porque "as linguagens que preenchem o espaço semiótico são diversas e se relacionam umas com as outras ao longo do espectro que vai da completude traduzibilidade mútua até a completa intraduzibilidade” (MERREL, 2003, p. 166). Em outras palavras, se colocarmos as categorias de Pierce - primeiridade, secundidade e terceiridade, no contexto da biosfera de Vernadski e da semiosfera de Lotman, “veremos a formação de múltiplos nós borromeanos de inter-relações que estão em movimento fluido e perpétuo dentro e fora um do outro enquanto entram e saem de inter-relações triádicas” (Ibid., p. 165). Ao mesclar as idéias de Lotman com as intrigantes tríades de Pierce, à luz de sua postura anticartesiana, Merrel faz emergir da sopa semiótica algo de novo, comentando que "primeiridade, homogenia e todo o edifício 
científico se tornaram cada vez mais heterogêneos, em vez de simplesmente maniqueísta, dualista e hegemônico" (Ibid., p. 171).

Logo, é preciso ser surpreendido pelo inesperado, procurar erros, diferenças, evidências negativas, eventos que não deveriam acontecer no palco sobre o qual nos encontramos. A vida cotidiana é permeada por essas ações, reações e interações com indícios e itens efêmeros que nos cercam. Na concepção de De Certeau (2007), as respostas criativas das pessoas mantêm o coração e os pulmões do organismo social funcionando, pois a cultura popular é sobretudo criativa. Portanto, “o apropriador do signo deverá entrar no jogo, interagindo com ele, com seu criador e com todo o ambiente, empurrando seu significado para uma finalização possível (...)”, mas não completa (MERREL, 2003, p. 176).

Outro nicho contido no espaço semiótico é a logosfera, entendido como o reino da palavra, porta-voz da informação semiotizada e nascente da cultura (MACHADO, 2010). Nesse sentido, o conceito de espaço não está relacionado somente ao visual, mas ao sensório (sensível/estético), com reverberações na própria configuração espacial. Para ampliar o primado da logosfera, Lotman (1990) entende que só sistemas dotados de inteligência podem constituir pensamento e abranger o campo do sentido, onde quer que ele se manifeste, o que parece ser o caso da cultura, formulada pelo pesquisador como dispositivo pensante dotado de inteligência e memória, de ordenamento e capacidade gerativa, como espaço da mente (MACHADO, 2007b). Assim, a semiosfera suplanta a logosfera, pois o questionamento fundamental é o caráter singular da linguagem na cultura, em prol de uma compreensão de seus extratos não linguísticos propriamente ditos, mas semióticos, como códigos culturais (visuais, sonoros, gestuais, cinésicos) criadores de sistemas específicos da semiótica (MACHADO, 2003).

Se a vida no planeta, biosfera, está assegurada pela biodiversidade das espécies, a vida na cultura, semiosfera, só pode sobreviver através da semiodiversidade. Logo, natureza e cultura são sistemas que se implicam mutuamente, cujas fronteiras devem ser totalmente movediças entre o “dado” e o “criado”. Nesse sentido, entendemos que semiótica da cultura surge como um desdobramento teórico da semiótica da comunicação, ao encontro do que Lotman denominava culturologia, como uma necessidade crescente de conhecer as linguagens produzidas pelos sistemas de culturas, suas mediações e (res)significações nos diferentes espaços culturais, capazes de criar um continuum semiótico, como entendeu o teórico ao explicitar a cultura como texto (MACHADO, 2007a). “Com isso, cultura e não cultura tornam-se termos de um repertório conceitual que movimenta formulações teóricas da 
cibernética, da teoria da informação, da mitologia, da literatura e da arte” e "desafiam o entendimento de como esferas de organização convivem com esferas entrópicas” (MACHADO, 2010, pp. 158-159).

Outro diálogo possível com o conceito são as relações entre semiosfera e a teoria da Umwelt, vista como uma biologia comportamental pelo seu formulador, o biólogo estoniano Jakob Johan Von Uexküll (1864-1944), sendo que ambas procuram uma compreensão ecológico-cognitiva da vida planetária e do universo, aproximando biosfera, noosfera (reino da mente, com emergência da consciência humana) e semiosfera, conforme mapeamento sobre o reino dos signos, anunciado por Pierce e, que na visão de Santaella (1995), foi perseguido por Monod, Morin e Jakobson, como uma disciplina que ombrearia com as demais hermenêuticas sociais, com imanência de valores e crenças sobre as condutas humanas. Já Poinsot, Scotus, Locke, entre outros pensadores, entenderam a doutrina dos signos como uma arquitetônica filosófica ocupada com a mente humana e seus modos de entendimento e produção de conhecimento (MACHADO, 2007a). Assim, signo gera signo, semelhantemente ao modo que texto gera texto cultural, que pressupõe a semiotização do entorno (Umwelt), pois “a cultura é um gerador de estruturalidade, cria à volta do homem uma sociosfera que, da mesma maneira que a biosfera, torna possível a vida, não orgânica, é óbvio, mas de relação” (LOTMAN; USPENSKIJ, 1981, p. 39).

A bolha de "realidade" e de "verdade" a que "estamos evolutivamente programados a conhecer é serva do aparato perceptivo-operacional com que a pulsão de permanência nos equipou”. Tal teoria da significação foi entendida por Uexküll mais como um jogo dicotômico e cíclico, entre uma "racional subjetiva” versus uma “fenomênica objetiva”: entre um mundo de dentro para fora (Umwelt) e um outro de fora para dentro (Innenwelt), entre um campo perceptivo-paciente (Merkwelt) e uma esfera operativa-agente (Wirkwelt). Portanto, a bolha Umwelt, “cuja programação semiósica agencia as limitações e possibilidades cognoscitivas específicas de cada espécie vivente: a miríade espontânea de fenômenos da Innenwelt é sempre filtrada pela polícia alfandegária da Umwelt” (ARAUJO, 2002, pp. 14-16). Essa “bolha fictícia”, esse "Universo particular” de uma espécie viva, constitui a inferface desenvolvida pela evolução para gerenciar a adaptabilidade e sobrevivência do sistema, conectando uma realidade objetiva e um sistema cognitivo (VIEIRA, 2007).

Thure Von Uexküll (2002), em artigo sobre sua teoria "sistêmica", elaborou os subconceitos nevrálgicos para formar o superconceito da Umwelt: a categoria do tempo e sua explanação continuísta do círculo funcional, para seguir ao código e ao contexto, distinguindo 
três tipos de semiose: informação (ambiente inanimado com papel de quase transmissor), sintomatização (ser vivo como transmissor de sinais por meio de seu comportamento ou direção ao recipiente para resposta) e comunicação (permissão ao transmissor e ao recipiente para compartilhar funções semióticas). A partir desse círculo funcional, estabelecemos mais uma interface com os conceitos de fronteira, imprevisibilidade, irregularidade e programa de ação, que integram a semiosfera de Lotman, quando o Umwelt é retroalimentado pelo Innenwelt.

Destacaremos aqui dois termos: imprevisibilidade e irregularidade, em relação à polaridade clássica sujeito versus objeto, idealismo versus realismo, no problema da essência do conhecimento (VITA, 1964). Imprevisibilidade sugere uma característica voltada à subjetividade ou ao sujeito, relacionada à sua capacidade (ou incapacidade) de fazer previsões acerca dos processos provenientes do mundo e aos quais é sensível. Imprevisível é algo em que não pode ser inferido ou sabido com precisão e certeza, por um sistema cognitivo. Já o termo irregularidade pode tanto ser aplicado ao domínio da subjetividade quanto da objetividade, pois a realidade tem o seu teor de irregularidade complexa, não sendo restrita ao ideal mecanicista newtoniano. Admitamos que exista um fundamento comum aos dois termos: imprevisibilidade seria uma faceta de algo mais geral, porque comum à objetividade, e esse algo seria a irregularidade, ou seja, a imprevisibilidade em um sistema cognitivo é uma irregularidade "interna” ao sujeito e que reflete, embora nem sempre, uma irregularidade “externa”. Assim, “Umwelt e consequentemente a semiosfera foram construídos em uma realidade que, objetivamente é preenchida por processos irregulares, sejam aleatórios, estocásticos ou de caos determinista” (VIEIRA, 2007, p. 102).

Lotman (1998), em seu capítulo sobre "O progresso técnico como problema culturológico”, menciona Kuhn (1989) no aspecto em que fora das paredes do laboratório a vida cotidiana segue seu curso, ou seja, o estudo das consequências de grandes revoluções e novos paradigmas científicos adquire no presente um caráter não somente acadêmico. Mais tarde, em conversa com Torop, afirma:

O destino das pessoas, a história, as realizações das ciências são imprevisíveis. (...) A propósito, imprevisibilidade (...) cujo mecanismo é um dos mais inusitados da ciência, uma vez que introduz nela um elemento completamente singular: o componente da arte. (...) A arte sempre se orientou em direção à imprevisibilidade. No meu modo de ver, o mais interessante que está acontecendo neste momento é aquilo que entendo como estetização da ciência. (...) É sabido que nós podemos viver num mundo que se baseia no modelo da ciência ou que nós podemos viver num mundo que é baseado numa unidade conflitiva desses dois modelos. (LOTMAN apud TOROP, 2000, pp. 13-14) 
Em A estrutura do texto artístico, Lotman (1978, p. 27) comenta sobre a essência da arte, que se assemelha “à necessidade do saber”, sendo "uma das formas de conhecimento da vida” e “de luta da humanidade por uma verdade que lhe é necessária”. Trata-se de "um gerador notavelmente bem organizado de linguagens de um tipo particular, que prestam à humanidade um serviço insubstituível ao ser aplicada a um dos lados mais complexos do saber humano" (Ibid., p. 30), porque "a linguagem da arte modeliza os aspectos mais gerais da imagem do mundo", e o valor de sua mensagem muda conforme a estrutura do código do leitor, segundo suas exigências e expectativas (Ibid., p. 52). Portanto, a humanidade necessita de possibilidades para gerar linguagens sempre inovadoras que possam expressar novos horizontes à sua necessidade de conhecimento e é a partir dessa demanda que o estético se impõe com sua importância semiótica e histórica, portando uma conectividade com o mundo capaz de modelizá-lo de forma inventiva. Tal pensamento fica claro quando Lotman (Ibid.) diz que o mundo da semiose não está fatalmente fechado em si, mas forma uma estrutura complexa e heterogênea que, continuamente, joga com o espaço que lhe é externo.

Lozano (1999) também destaca que essa perspectiva sinaliza uma grande inovação na proposta do semioticista, que altera toda uma tradição imanentista do modo como a semiótica, herdeira ou do estruturalismo ou do formalismo, concebia seu objeto de análise: um texto como uma entidade separada, isolada, estável e autônoma. "Em Lotman, o texto transforma-se em espaço semiótico no interior do qual as linguagens interagem, se interferem e se autoorganizam hierarquicamente” (HENN, 2010, p. 112).

Com base nessas considerações entre ciência e arte, e com foco nas discussões do conceito de tempo, o atual cisma cartesiano nas ciências culturais e naturais revelam, por um lado, filósofos como Bergson, Husserl e Heidegger que exponham suas ideias de experiência humana temporal e, por outro lado, físicos definam o conceito de tempo para medição e descrição de seus resultados. A partir da primeira corrente, Uexküll (2002) desenvolveu sua teoria da significação, em que o presente funciona como um signo e o futuro como o significado, quando no campo da cultura, há o estabelecimento de várias relações contextuais, com interpretações de outras interpretações, ou seja, as metainterpretações.

Em complemento à proposta de Uexküll e mediante algumas definições de cultura espalhadas pelos textos de Lotman (1990, p. 31), podemos descrevê-la como “o conjunto de informações não hereditárias que as diversas coletividades da sociedade humana acumulam, conservam e transmitem”. Esse entendimento coloca para os pesquisadores de mídias uma questão importante: quando se lida com fenômenos culturais da contemporaneidade, em 
algum nível se trabalha com o problema da memória coletiva, vetoriada para um possível futuro. Trata-se de uma dinâmica já antecipada por Peirce para quem todo o processo de semiose é orientado por uma meta que associa o desvendamento de um objeto dinâmico (portador de memória) e sua potencial reconstituição pelos sistemas de signos, num movimento sempre in futuro (HENN, 2010).

Outra das contribuições de Uexküll (2002) foi mostrar que o argumento positivista é resultado de dois equívocos, a saber: o primeiro se refere à premissa infundada de que a física e a química revelariam a realidade (um mundo de “coisas-em-si”, conforme Kant), independente do observador humano, que os projeta na natureza; o segundo equívoco, supõe que as interpretações físico-químicas dos processos em sistemas vivos e as interpretações sígnico-teóricas seriam mutuamente excludentes. Mas tais abordagens são complementares, pois a realidade objetiva das ciências naturais é uma construção mental, e todas as metáforas sobre as quais podemos esboçar para a interpretação dos estímulos são derivadas da experiência humana de nosso próprio eu.

Há na filosofia um conceito que reflete o caráter do Umwelt expandido e contém características da semiosfera: é a mundividência, ou seja, a visão de mundo que qualifica como um ser humano ou um grupo de pessoas encontra-se inserido em condições sistêmicas complexas. “Todo homem, com maior ou menor clareza, reflete sempre, em seu espírito, as relações que ocorrem entre ele e seu ambiente”, não meramente o físico, mas também o psicológico e o cultural (VITA, 1964, p. 21). Assim, mundividência se manifesta em três níveis: o da vontade, o do sentimento e o da racionalidade. Vale notar a analogia entre essa divisão e aquela proposta por Pierce: o interpretante energético, o emocional e o lógico (VIEIRA, 2007).

Podemos dizer também que o aspecto específico da teoria dos signos de Uexküll é a introdução do intérprete como um elemento essencial de cada semiose, que complementa o interpretante de Pierce, em sua tríade - signo, interpretante e objeto significado. Assim, o problema do observador humano e seu papel como intérprete de processos sígnicos vegetais e animais são as perguntas essenciais dessa abordagem. Concordamos com (MACHADO, 2010, p. 165) que, se coube aos estudos sobre semiosfera compreender a relação entre cultura e não cultura no continuum semiótico, “caberia à ecologia semiótica dimensionar as semioses no sentido de observar as expansões das ações qualificadas não só da cultura em direção à natureza, como também o oposto”. 
Portanto, a premissa elementar afirma que, ao construir a compreensão da natureza, o ser humano constrói a própria natureza em contexto, em seu entorno, ou seja, uma natureza “culturalizada”. A questão é o que existe de natureza na experiência da vida na cultura, quais naturezas são reproduzidas nas diferentes formas de Umwelt das espécies. É no contexto da semiosfera, que Kull (1998, p. 36) formula a hipótese de que “a nossa natureza é a cultura”, isto é, há um modus operandi em que cultura é fruto da semiose da própria natureza, ou melhor, das transformações dialéticas da natureza, conforme Engels (1979). Portanto, a grande delação seria superar o “dualismo existente entre mente e matéria” (KULL, 1998, p. 349), "num espaço que repercute em outros, porque todos convivem na semiosfera e são permeáveis às flutuações que gravitam em seu entorno (MACHADO, 2010, p. 166).

No campo da terminologia interdisciplinar, está associado, de um lado, a biosfera e a noosfera; e de outro, a logosfera. Com um pensamento transdisciplinar contemporâneo, Torop (2007) entende que a semiosfera está muito próximo do conceito de símbolo (indefinível) no simbolismo, marcando a complementariedade de disciplinas para estudos gerais da cultura e como "metodologia" de entendimento. No contexto das tendências científicas atuais, semiosfera é simultaneamente um objeto e um metaconceito, ou seja, é o que está sendo estudado na e como cultura e é também o método de estudo da cultura. Esta, por sua vez, com seu dinamismo, obriga a ciência a procurar novas linguagens descritivas, oferecendo outras possibilidades de auto e/ou metadescrição, por meio da crioulização ou "mestiçagem" (MERREL, 2003, p. 182), quando a ciência dos signos aproxima-se da arte dos signos. Portanto, não é paradoxal que a semiosfera estude a semiosfera e a cultura estude a cultura, pois ao criar tratamentos culturais nós também podemos ser parte da criatividade cultural.

A partir do pressuposto de que “sem paradoxo não há significação”, Kull (2007, pp. 71-73), sintetiza algumas definições de semiosfera, propostas por participantes no Primeiro Encontro Internacional para o estudo de Semiosfera, ocorrido em 2005, em São Paulo, como: conjunto textual; formada por uma rede (interminável) de interpretações; esfera da comunicação; rede processual de signos ou semioses; lugar de todas as Umwelts interconectadas; espaço de semioses; espaço de geração de sentido; espaço da relação partetodo; lugar onde as distinções acontecem; espaço da diversidade qualitativa; esfera de cura; mundo de múltiplas verdades; totalidade de "duetos contrapontísticos”; totalidade de signos interconectados, que cobre a terra.

Lotman (1990) também desenvolve sua semiótica da cultura por meio de uma linguagem cheia de metáforas espaciais, evocando imagens de espaços abertos, de dimensões 
galácticas. Em outros textos é possível encontrar imagens de territórios fechados, separados por limites, reflexos de outros espaços dentro deles próprios, como espelhos refletindo o espaço onde eles estão inseridos. Tais imagens implicam inconsistências, conduzem a catacreses ou resultam em paradoxos enigmáticos, como na epígrafe citada na introdução deste trabalho, ou em outras passagens semelhantes, tais como: “o espaço real é uma imagem icônica da semiosfera, uma linguagem na qual vários significados não espaciais podem ser expressos, enquanto a semiosfera em si transforma o mundo real do espaço no qual vivemos em sua imagem e semelhança” (Ibid., p. 191). Segundo sua teoria, metáforas são semiosferas representando imagens mentais por meio de signos verbais, para serem lidas igualmente como autorreferenciais, pertencentes ao nível de modelização secundária, pois medeiam diferentes esferas semânticas (NOTH, 2007).

Com relação às diferentes funções cognitivas dos dois hemisférios do cérebro humano, Lotman (1990, pp. 36-37), formula o paradoxo crucial que "dentro da consciência existem duas consciências", criando dois tipos de "textos”, verbal (conjunto de signos discretos lineares) e pictórico (espaço visual não discreto). Ao enfatizar a diferença essencial entre textos discretos e não discretos, postula a impossibilidade de sua mútua traduzibilidade, dilema esse que só pode ser superado por meio de metáforas, que funcionam como mediadores entre as duas esferas da mente humana, provocando novas "associações semânticas” e sendo "mais que um mero ornamento retórico". Tal mecanismo é fundamental "para a construção de um conteúdo que não poderia ser construído por apenas uma linguagem”, pois “um tropo é a figura nascida no ponto de contato entre duas linguagens” (Ibid., p. 44).

Além disso, a tendência sinistro-hemisférica, já defendida por Pierce, que injeta no hemisfério direito possibilidades criativas, entre outros aspectos, caracteriza-se por um incremento da semioticidade, como um processo gerativo da construção inventiva de signos que, por sua vez, produzem os sistemas culturais com imprevisibilidade, aleatoriedade e não causalidade. De fato, esse é uma das grandes delações, tanto no campo subjetivo quanto científico, pois desde o século XVIII a ciência se firmou como racional, com suas estruturas metodológicas verbais, formalizadas na escrita científica, em detrimento do estético, restrito ao mundo das belas-artes (HARVEY, 1993; BAIRON, 1995 e 2004; SANTAELLA, 2001 e 2007).

Se entendermos que cultura se manifesta de forma tridimensional, descrevê-la como um espaço é utilizar-se amplamente de termos metafóricos. Seu potencial criativo e sua 
habilidade para expressar analogias entre diferentes esferas de pensamento e experiência, tornam as metáforas ferramentas úteis tanto para poetas e oradores como também para cientistas, pois "retórica é tanto parte da consciência científica quanto da consciência artística” (LOTMAN, 1990, p. 45). “A questão que se coloca é: por que Lotman não avança um degrau a mais para postular uma ubiquidade das metáforas que se estendem para o comportamento cotidiano verbal e não verbal indistintamente?”

A predominância de esquemas de imagem espacial de metáforas cotidianas, representando conceitos abstratos, tanto quanto no discurso teórico, são reflexos e, por conseguinte, signos de nossa cognição espacial, nossa experiência corporal de orientação humana no espaço. (...) Se nós interpretamos a ideia de modelização primária como referente à semiose préverbal, no sentido cognitivo e evolucionário (...), a teoria da metáfora como modelização secundária de signos pode adquirir uma nova, mas bem diferente relevância semiótica (NOTH, 2007, p. 84).

Apesar da dimensão galáctica evocada pelo conceito de semiosfera, o referido pesquisador não admite a visão pansemiótica do universo no qual signos e semiose sejam ubíquos, oferecendo uma visão dualista da mente constituída de uma esfera semiótica e não semiótica, compreendendo essa última, objetos desprovidos de “semiotização”, ou seja, que não têm significado cultural e são "simplesmente eles próprios” (LOTMAN, 1990, p. 133), sendo que as fundamentações filosóficas dessa teoria são claramente baseadas na fenomenologia de Husserl (NOTH, 2000).

Uma segunda lacuna presente na pesquisa de Lotman sobre semiosfera está na quase preocupação exclusiva com textos e códigos gerados por sistemas modelizantes secundários, que parece excluir ocasionalmente a linguagem cotidiana, pelo menos quando define linguagem (cotidiana) como um sistema modelizante primário, e a semiosfera como o primado dos sistemas modelizantes secundários. Porém, em que sentido são os modelos verbais do mundo primários?

A distinção nítida de Lotman entre codificação primária e secundária não está privada de inconsistência. Se as metáforas pertencem à esfera da modelização secundária, e assim, à semiosfera, e os animais, que também usam metáforas e também se comunicam, então não se pode admitir que animais não se comunicam, nem que eles sejam excluídos da semiosfera. Parece muito dualista a oposição rígida entre semiosfera da cultura humana e a do mundo não semiótico dos animais e objetos em uma esfera sem significado cultural. (...) Bakhtin teve um insight mais moderno sobre a natureza da linguagem quando afirmou, em 1930, que "todos os signos estão sujeitos à avaliação ideológica” e que "o domínio da ideologia coincide com o domínio dos signos”. (...) A linguagem natural é permeada de metáforas; os signos verbais quase nunca são representações simples ou primárias do mundo. (Ibid., p. 89). 
Entretanto, apesar do dualismo fundamental presente na distinção entre modelização primária e secundária, o sistema criado pelo semioticista é mais diferenciado do que seus dualismos podem sugerir, pois sua descrição de semiosfera é um sistema autorreferencial, criando suas próprias meta-semiosferas em espelhos, capazes de caracterizar a relação de iconicidade entre dois espaços (LOTMAN, 1990, p. 55), como verificamos a seguir:

Se a semiosfera é um espaço semiótico no qual a cultura está imersa, um espaço que é anterior mesmo ao que ele cria, e se os espaços que ele cria são também semiosferas, nós chegamos a um paradoxo, pois o que mais pode ser a semiosfera no qual a cultura está imersa ser senão uma esfera cultural? Como pode a semiosfera ser tanto o espaço que cria cultura e o próprio espaço cultural? Como pode a cultura preceder a linguagem, quando a linguagem é definida como cultura? O tipo de paradoxo com o qual nos deparamos neste ponto não necessariamente implica autocontradição; é bem conhecido na teoria dos sistemas autorreferenciais. (...) É uma descrição coerente da cultura no estágio em que cultura cria e é criada pela cultura. (NOTH, 2007, p. 92).

\subsection{Da Semiosfera à Ludusfera}

Com ou apesar das máquinas, mecânicas, eletrônicas, analógicas ou digitais, entendemos que as linguagens se diversificam, e a semiosfera ganha corpo em outros suportes. De um lado, informações estéticas experimentais e fora dos cânones e, de outro, experiências estéticas de comunidades marginalizadas, produzem movimentos inovadores. $\mathrm{O}$ mercado, ao necessitar de novidades, pode se apropriar e reduzir o caráter inventivo dessas produções, porém cabe à ciência experimentá-las e investigá-las, pois há nelas a memória artística no sentido que Lotman previu que pode estruturalmente se reconstituir gerando textos com as marcas do estranhamento e da invenção (HENN, 2010).

Se “a fruição sensorial supõe a aplicação de códigos múltiplos e variados” (LOTMAN, 1978, p. 116) e se existe uma experiência modelizante para a qual a diferenciação entre atividade prática e trabalho mental não é apropriada, seria o jogo, que "não se opõe nunca ao conhecimento: pelo contrário, ele é um dos meios mais importantes de aquisição das diferentes situações vitais de aprendizagem de tipos de comportamento” (Ibid., pp. 119-120). Nesse sentido, o jogo é um sistema da cultura modelizador de situações inesperadas e novas, pois uma situação real pode ser substituída por outra lúdica, fazendo com que o jogador perceba a possibilidade de suspender uma ação, como o “é sua vez” do jogo, cuja realidade e regras podem ser reformuladas. Concordamos com o semioticista que "o jogo supõe a realização simultânea (e não de mudança consecutiva no tempo!) do comportamento prático e convencional” (Ibid., p. 121), pois “modeliza a contingência, a determinação incompleta, a 
probabilidade dos processos e dos fenômenos” (Ibid., p. 124). Se a arte possui uma série de traços que a assimilam ao lúdico, torna-se infundado

o medo de uma série de estéticos em se ocuparem dos problemas dos jogos (a fim de evitar as acusações do kantismo) e a sua profunda convicção de que qualquer confronto entre o jogo e a arte conduz a uma profissão de "arte pura”, à negação do laço entre a obra e a vida social, refletem o seu profundo desconhecimento das questões das ciências conexas (psicologia, pedagogia). (Ibid., p. 121).

O ser humano, chamado de Homo sapiens, merece também ser chamado de Homo ludens, pois considera o jogo toda e qualquer atividade humana, sendo presente em tudo o que acontece no mundo. Portanto, jogo é um fenômeno cultural e não biológico, e implica regrafundamento da linguagem, entendida por Lotman (1978) como sistema modelizante primário, isto é, intrínseco ao ser humano, limitando os demais à condição de sistemas modelizantes secundários, como releituras e reelaborações do próprio homem. A atividade lúdica é a modelização da regra: de lógica para lúdica. Esse é um dos aspectos fundamentais para a compreensão do jogo como texto: a interação entre regra e jogo ou entre lógica e lúdico.

Baseado em seu livro sobre Multimídia, Bairon (1995) compara a hipermídia ao conceito de jogo, elaborado por Huizinga (1971) em Homo ludens, com a abrangência de brincar, experimentar, representar, construir, tocar, jogar, competir, entre outras manifestações (FREIRE, 2005). Lévy (1993) também defende que a multimídia interativa, por sua dimensão reticular, promove uma atitude lúdica. Assim, destacamos que o conceito de interatividade hipermidiática está sob a semiosfera do jogo (que intitulamos ludusfera), que por sua vez é integrado no de cultura, pois é no jogo e pelo jogo que a civilização surge e se desenvolve.

Ao situar o lúdico como elemento da cultura, Johan Huizinga analisa que as grandes atividades arquetípicas da sociedade são, desde o início, marcadas pelo jogo, tais como a linguagem, esse primeiro e supremo instrumento que o homem forjou a fim de poder comunicar, ensinar e liderar. Um segundo exemplo é o mito, uma transformação ou imaginação do que é exterior. O ser humano, por meio da abordagem mitológica, procura dar conta do mundo fenomenológico, atribuindo-lhe um fundamento divino. Outra ilustração é o culto, com a celebração de ritos sagrados, sacrifícios, consagrações e mistérios, procurando assegurar tranquilidade ao cosmos, dentro de um espírito de puro jogo. Ora são no mito e no culto que têm origem as forças instintivas da vida civilizada, as raízes no solo fértil do jogo sub specie ludi - direito/ordem, comércio/lucro, indústria/arte, sabedoria/ciência. 
Em um de seus artigos, Bairon (2007a), pontua que, quando considerado sob a perspectiva da fenomenologia (HEIDEGGER, 1978), a ação do jogar possível na hipermídia assume um caráter fundamental, pois constitui uma das formas privilegiadas de aproximação e apropriação do mundo, ou seja, de construção do conhecimento, por meio de desafios e associações (jogo equivalente ao termo alemão Spiel: interpretação, risco, brincadeira). A partir do ponto de vista fenomenológico, aliado à psicanálise, o jogo é resultante do investimento de uma função constitucional do sujeito falante, desde as primeiras brincadeiras infantis, mesmo no período pré-linguístico, porém interpretativo, exemplificado no impulso de lançamento do carretel e no seu recolhimento, como manifestação lúdica que promove a permutabilidade do significante dentro da ausência/presença do outro no Outro (LACAN, 1973). “Jogando, o homem constrói o universo de interpretações que forma a tessitura dos campos semânticos por onde transita” e, deste modo, “jogo e linguagem devem ser compreendidos como cooperativos desde a tenra infância” (BAIRON, 2007a , p. 96) para, posteriormente, unirem-se num mesmo fenômeno: a antecipação de sentido, tão trabalhada pela hermenêutica (GADAMER, 2008), como uma estratégia cuja resposta conduz a uma nova pergunta, e a circularidade da compreensão, sendo que o perguntar é a essência inaugural e final da própria compreensão (HEIDEGGER, 1978).

Portanto, segundo Bairon (2007a , p. 97), “devemos encarar a própria atividade do jogo como uma hipermídia, enquanto base tecnológica que é capaz de revigorar conceitos cada vez que ela é colocada em ação”, com propostas interdisciplinares, desde seus fundamentos filosóficos às soluções técnicas respectivas, de modo que essa base tecnológica age como uma linguagem, na qual se realiza a compreensão e cuja realização se dá na interpretação (GADAMER, 1991 e 2008; WITTGENSTEIN, 1989). "Para a hermenêutica gadameriana, o modo de ser do jogo tem sua melhor existência como expressão na experiência estética”, pois não se trata “do jogo com a linguagem, mas de jogos de linguagem, onde a mais consequente comunicação está no vaivém estético entre conhecimento científico e sensus communis”, ou seja, um jogo de interpretações entre pesquisador e informantes, quando a realidade se apresenta pela aparência e pela ilusão (BAIRON, 2007ª , pp. 102-103). Por sua vez, “os jogos de linguagem de Wittgenstein lembram que as formulações mais profundas da filosofia estão localizadas nas coisas e ideias corriqueiras que, em si mesmas, já fazem com que a compreensão sucumba no seu interior” (Ibid.; MORENO, 1995).

Sobre a dimensão conceitual da comunicação nas esferas e a dimensão da experiência estética em sua expressividade hipermidiática, Bairon (2010) destaca a trilogia filosófica 
Esferas de Sloterdijk (1998, 1999, 2004), perpassando pela fenomenologia heideggeriana, como uma forma de compreensão da contemporaneidade, com base nos seguintes princípios: historicidade multifocal, linguagem hipermidiática, comunicação heterárquica e diálogo multiperspectivista.

Em Esferas I - Bolha, Sloterdijk propõe um conceito que detém a capacidade de reter características topológicas, antropológicas e semiológicas. Trata-se da microesfera, cuja “expressividade mais consistente está calcada nos casais, nos pares e não no indivíduo”; uma espécie de saber não sabido, mediante a experiência desde o útero, como uma "ginecologia filosófica”, existente desde a primeiridade em forma de nicho ecológico, e a necessidade de construir nossa própria habitação, com uma gruta topológica do cotidiano (BAIRON, 2010, pp. 19-20).

Já Esferas II - Globo, trata “da ação de um empreendimento novelístico-filosófico que constrói, por meio de narrativas e subnarrativas, o arredondamento do mundo" (SLOTERDIJK, 1999, p. 45). Como um entorno imaginário (Unwelt), “a linguagem que temos aqui se manifesta na saída da familiaridade (a cabana), passando pela cidade moderna e pelo império, até, finalmente, se expandir no espaço ilimitado e imensurável”, identificando a globalização terrestre a que seguiu o perguntar metafísico e antecedeu o advento das telecomunicações digitais (BAIRON, 2010, p. 20).

Numa trajetória adversa às Esferas anteriores, Esfera III - Espumas destaca a “vida” que se desenvolve de modo reticular, hipermidiático e heterarquicamente, quando a comunicação, que só existe em mobilidade, se articula em cenários simultâneos, uma vez que produz e consome conteúdo em oficinas interconectadas.

A metafórica e dinâmica constituição das espumas serve para recuperar pósmetafisicamente o pluralismo pré-metafísico das facções do mundo. (...) uma experiência que direcione ao estético, pois a compreensão do amontoamento, mediante globos simplificadores, não proporciona mais uma justificativa que dá ao desordenado um todo. (...) Tal como Sloterdijk, parto do princípio de que, no universo da experiência estética, a imagem participa diretamente da essência da compreensão, pois tudo aquilo que está expresso volta-se a si mesmo, ou seja, está por si mesmo em sua imagem. (...) A compreensão deve mostrar-se como fragmento de um sentido que se constrói em todo o enunciado identificado como experiência estética, tanto na ciência como na filosofia. (Ibid., p. 20-21)

Com uma composição fugaz de concavidades gasosas, que triunfou sobre o sólido como um golpe de Estado noturno, a espuma e seu modelo visual se apresenta como uma insolente subversão filosófica da ordem no meio. Portanto, “fluidez" ou "liquidez” são as principais metáforas para a atualidade, visto que os líquidos fluem, escorrem, inundam, vazam 
e são leves, moldáveis e filtrados, diferentemente dos sólidos, cujo “derretimento” já havia sido hasteado por Marx e Engels - “Tudo o que é sólido se dissolve no ar”, autores do Manifesto do Partido Comunista, que pretendiam construir uma nova ordem com inovados e aperfeiçoados sólidos. Mais tarde, tal herança marxista influenciaria os teóricos críticos da Escola de Frankfurt, que interpretavam "o leve como aparência e o pesado como essência”, sucumbindo à crítica no velho estilo, ou seja, "expondo a leveza da aparência em nome do peso do real” (SANTAELLA, 2007, p. 23).

Por meio dessa digressão de liquidez versus solidez, o sociólogo polonês Bauman (2001, p. 11) norteia que o presente surgiu “do derretimento radical dos grilhões e das algemas que, certo ou errado, eram suspeitos de limitar a liberdade individual de escolher e de agir. A rigidez da ordem é o artefato e o sedimento da liberdade dos agentes humanos”, de tal modo que “os poderes que liquefazem passaram do 'sistema' para a 'sociedade’, da 'política' para as 'políticas de vida' - ou desceram do nível 'macro’ para o nível 'micro’ do convívio social” (Ibid., p. 14), à semelhança da habitação de uma casa: “com imagens, sons, diálogos, caminhadas, numa frequente interação com as coisas que ali colocamos e que nos interpelam” (BAIRON, 2010, p. 23).

Esse encurtamento do ser ao espaço do interminável, sempre teve a sua garantia na experiência estética, pois na visão de Pierce (1987, p. 58) “a minha linguagem, assim, é a soma de mim próprio, porque o homem é o pensamento”. Sob essa semiótica,

\footnotetext{
ser e linguagem são a mesma coisa. Não há como instrumentalizar os signos para entendermos sua essência, assim como não podemos pensar sem signos. Nenhum pensamento precede o império dos signos, pois é sempre o resultado de uma semiose ilimitada, tal como na rede lacaniana de significantes. (BAIRON, 2010, p. 26)
}

Na semântica da palavra “obra”, lembra-nos Gadamer (1991), encontramos a palavra téchne, envolvendo a capacidade psíquica de planejar, criar, buscar, sintetizada no saber daquele que faz e constrói. "Se o uso é a forma mais primitiva de acesso à compreensão do mundo que se apresenta a nós por meio das ferramentas presentes no cotidiano”, entendemos que “o maior desafio concentra-se no desenvolvimento da criação e reflexão analíticas, que pode emergir da experiência com o mundo técnico da dialogia digital”. Portanto, “a experiência estética deve responder à pergunta pela técnica”, por meio da hipermídia que, “para ser reconstruída e/ou desmistificada, só é possível fazê-lo imerso no seu mundo” (BAIRON, 2010, pp. 25-26; SLOTERDIJK, 2004). “É como se a linguagem hipermidiática tivesse a possibilidade de demonstrar a utensilidade dos conceitos, sem que perdêssemos a sua complexidade” (BAIRON, 2007b, p. 46). 


\section{CONSIDERAÇÕES}

É a partir de nexos e lacunas referenciados no conceito de semiosfera de Lotman, de seus interlocutores, dentre outros autores, mediante relações teórico-filosóficas-metodológicas, com abordagem interdisciplinar, que desenvolveremos uma investigação futura, para a construção do metaconceito de Ludusfera, como filosofia do jogo de linguagem na hipermídia, tendo em vista as premissas seguintes:

- Necessidade de ampliação da teoria de Lotman, particularmente nos aspectos de oposição entre textos discretos (verbal) e não discretos (visuais) e na sua conceituação de semiosfera como a esfera de sistemas modelizantes secundários que ocasionalmente parece excluir a linguagem cotidiana, pelo menos quando ele define a linguagem (cotidiana) como sistema modelizante primário, conforme apontados por Nöth (2007), construindo o metaconceito de Ludusfera, como uma filosofia do jogo de linguagem na hipermídia.

- Tendência da ciência em eliminar a imprevisibilidade e controlar o ambiente, com perda do componente do acaso, que são elementos frequentes do senso comum/cotidiano, mas que também estão presentes nas escolhas do investigador e motivam boa parte dos encontros/desencontros, das ferramentas teóricas, das disciplinas envolvidas e das realizações de projetos de pesquisa.

- Interdisciplinaridade como uma aspiração emergente de superação da racionalidade científica positivista e hegemônica, visando novas formas de: produção de conhecimento, construção de paradigmas científicos inovadores, articulação da pluralidade dos saberes em torno de problemáticas comuns, desenvolvimento de trocas de experiências e modos de realização de parcerias do saber à comunidade, com indissociabilidade de pesquisa, docência e extensão (BAIRON, 2010, 2008, 2007ab, 2002).

- Importância da reflexividade no encontro entre culturas (semiosferas), apontando para a própria subjetividade do investigador na sua relação com o objeto, com foco na inseparabilidade dos saberes (científico e artístico, humanístico e tecnológico, local e global) e das atividades de investigação, ensino e serviço à comunidade e/ou ao mercado (Ibid.).

- Emergência de novas tecnologias do saber, novos olhares e procedimentos que põem em causa a própria noção de objeto, com destaque para a reflexão hipermidiática que é, desde o início, um conjunto de inter-relações híbridas (matrizes visual, sonora e 
textual), contrariamente à tradição ocidental que, a partir do século XVIII, separou-se da pesquisa multimidiática e passou a valorizar somente o livro como códice.

- Desafios da margem digital em aprofundar as interligações temáticas entre fundamentações filosóficas, teóricas e metodológicas, dispostas nesta ordem e tão necessárias à produção consequente de todo conhecimento científico (BAIRON, 2007ab).

- Entendimento da hipermídia como um jogo originário de pesquisas acadêmicas, construído no interior de um projeto estético conceitual, ou seja, uma expressividade da linguagem que tem por objetivo a produção do conhecimento, como uma potencialidade reflexiva no meio acadêmico, baseada na exploração reticular de conteúdos teóricos e na inventariação multimidiática para oferecer aos usuários a possibilidade de jogar com uma estrutura analítico-conceitual (BAIRON, 2010, 2008, 2007ab, 1998).

- Valorização dos caminhos reticulares do modo de ser da compreensão das potencialidades hipermidiáticas, tais como o equívoco, a pergunta, a antecipação do sentido e a circularidade da compreensão, articulados como grandes parceiros do ato de compreender e produzir conhecimento (HEIDEGGER, 1978; GADAMER, 2008, 2007 e 1991; BAIRON, 2010, 2008, 2007ab, 2000).

- Possibilidades de construção de um ambiente digital que ofereça a demonstração de contextos cotidianos, com troca de táticas e estratégias de produção de sentidos, nos quais tempo e espaço subvertem a unicidade e a sequencialidade do conteúdo, pois a tecnologia não pode inaugurar um mundo totalmente novo, mas ela participa de uma complexa rede de transformações culturais, além de conservar ações ancestrais (DE CERTEAU, 2007; BAIRON, 2010, 2008, 2007ab).

- Ressignificação do pensamento científico e sua ampliação estético-conceitual por meio do jogar hipermidiático, com valorização de atuação do hemisfério esquerdo (sensitivo e imprevisível), além do direito (racional e previsível), enaltecido pela tradição sequencial e lógica da ciência moderna que segue o princípio cartesiano de não tomar por certo nada sobre o qual haja alguma dúvida.

A magia da margem digital faz do movimento sua ludicidade existencial e faz do ícone, sem precisar descrevê-lo com significantes. Podemos imergir, e os objetos podem emergir como fruto da proximidade entre imagem e conceito. Se na leitura da letra na margem transformamos em som toda a palavra lida, no interior da margem digital podemos transformar em leitura o som, em imagem a leitura, em movimento a imagem, em arte a ciência e em ciência a 
arte. A trajetória da leitura não é mais única, mas múltipla e superlativa. (BAIRON, 2008, p. 21)

Enfim, para desenvolver uma pesquisa consequente sobre o campo conceitual da Ludusfera, proporemos uma reflexão tridimensional: filosófica, teórica e metodológica, para a investigação da interatividade da hipermídia como comunicação integrada. Com inspiração em filósofos e teóricos interdisciplinares, isto é, "imersos no mundo", como Bauman, Sloterdijk, Bakthin, Lotman, Uexküll, Pierce, Kuhn, Morin, De Certeau, Heidegger, Gadamer, Wittgenstein, Huizinga, Bairon, Santaella, Machado, entre outros, comunicaremos uma fundamentação da semiótica cultural, da fenomenologia e da hermenêutica centrada em jogos de linguagem (Spiel), para a construção do metaconceito de Ludusfera. Para a compreensão de expressividades hipermidiáticas faz-se necessário unir experiências estéticas, ludicidade e conhecimento, visando novos paradigmas científicos, além de suas possíveis extensões e (re)criações pelo senso comum.

\section{REFERÊNCIAS}

ARAÚJO, Eduardo Fernandes. A teoria do Umwelt de Jakob von Uexküll: apresentação. In: Galáxia - Revista Transdisciplinar de Comunicação, Semiótica, Cultura. São Paulo: PEPG em Comunicação e Semiótica, no. 3, 2002, pp. 13-48.

BAIRON, Sérgio. A Comunicação nas esferas, a experiência estética e a hipermídia. In: Cibercultura: Revista USP. São Paulo: USP, no. 86, jun/ago 2010, pp. 18-27.

A hipermídia como comunicação integrada e a retomada da experiência estética na produção do conhecimento. Tese de Livre Docência do PPGCOM USP, SP, 2008.

; RIBEIRO, José da S. O método etnográfico e a investigação hipermi(e)diática: um estudo de caso. In: Imágenes de la Cultura/Cultura de las Imágenes: interculturalidad, interdisciplinaridade, transnacionalismo. Murcia: Servicio de Publicaciones de la Universidade de Murcia, 2007a, pp. 79-114.

; RIBEIRO, José da S. A linguagem hipermidiática como produção do conhecimento: relações interdisciplinares. In: Antropologia Visual e Hipermedia. Porto: Edições Afrontamento, 2007b, pp. 43-60.

Texturas sonoras: áudio na hipermídia. São Paulo: Hacker, 2005.

.Tendências da linguagem científica contemporânea em expressividade digital: uma problematização. In: Informática na Educação: teoria \& prática. Porto Alegre, v. 7, n. 2, jul/dez 2004, pp. 101-156. 
Paulo: Futura, 2002.

Interdisciplinaridade: educação, história da cultura e hipermídia. São

; PETRY, Luis C. Hipermídia, psicanálise e história da cultura. São Paulo: EDUCS/Mackenzie, 2000.

A rede e o jogo. In: Casi Nada - Webmagazine, jul-ago 1998. Disponível em: http://solotxt.brinkster.net/csn/25rede.htm. Acesso em 20/06/2011.

Multimídia. São Paulo: Graal, 1995.

BAKTHIN, Mikhail. Estética da criação verbal. São Paulo: Martins Fontes, 2003.

BAUMAN, Zygmunt. Modernidade líquida. Rio de Janeiro: Jorge Zahar, 2001.

DE CERTEAU, Michel. A invenção do cotidiano. Rio de Janeiro: Petrópolis, 2007.

ENGELS, Friedrich. A dialética da natureza. Rio de Janeiro: Paz e Terra, 1979.

FREIRE, João Batista. O jogo: entre o riso e o choro. Campinas/SP: Autores Associados, 2005.

GADAMER, Hans-Georg. Verdade e método I: traços fundamentais de uma hermenêutica filosófica. Petrópolis/RJ: Vozes, Bragança Paulista, 2008.

Verdade e método II: complementos e índice. Petrópolis/RJ: Vozes, Bragança Paulista/SP: Editora Universitária São Francisco, 2007.

Estética y hermenéutica. Madrid: Technos, 1991.

KUHN, Thomas. A estrutura das revoluções científicas. São Paulo: Perspectiva, 1989.

KULL, Kalevi. Semiosfera e a ecologia dual: paradoxos da comunicação. In: Semiótica da cultura e semiosfera (Irene Machado, org.). São Paulo: Fapesp/AnnaBlume, 2007, pp. 69-79.

- Semiotic Ecology: different natures in the semiospheres. In: Sign Systems

Studies. Tartu: University of Tartu Press, vol. 26, 1998.

HARVEY, David. Condição pós-moderna: uma pesquisa sobre as origens da mudança cultural. São Paulo: Loyola, 1993.

HEIDEGGER, M. Filosofia, ciência e técnica. Santiago: Editorial Universitária, 1978.

HENN, Ronaldo. Memória e arte na semiosfera midiatizada. In: Conexão - Comunicação e Cultura. ICC, Caxias do Sul, v. 9, n. 18, jul/dez 2010, pp. 103-115.

HUIZINGA, Johan. Homo ludens. São Paulo: Perspectiva/EEDUSP, 1971.

LACAN, J. De um outro ao Outro. Seminário XVI, São Paulo: Ed. Samoa, 1973. 
LÉVY, Pierre. As tecnologias da inteligência - o futuro do pensamento na era da informática. Rio de Janeiro: Ed. 34, 1993.

LOTMAN, Iúri. Cultura y explosion. Lo previsible y lo imprevisible en los processos de cambio social. Barcelona: Gedisa, 1999.

El progreso técnico como problema culturológico. In: La semiosfera I. Semiótica de la cultura y del texto. Madrid: Cátedra, 1998.

. The Universe of the Mind. A Semiotic Theory of Culture. Bloomington: Indiana University Press, 1990.

Horizonte, 1981.

; USPENSKIJ, Boris; IVÁNOV, V. Ensaios de Semiótica Soviética. Lisboa:

. A estrutura do texto artístico. Lisboa: Estampa, 1978.

LOZANO, Jorge. Prologo. In: LOTMAN, Iúri. Cultura y explosion. Lo previsible y lo imprevisible en los processos de cambio social. Barcelona: Gedisa, 1999.

MACHADO, Irene. Cultura em campo semiótico. In: Revista USP. São Paulo, no. 86, jun/ago 2010, pp. 157-166.

Por que semiosfera? In: Semiótica da cultura e semiosfera. São Paulo: FAPESP/AnnaBlume,2007a, pp.15-23.

Circuitos dialógicos: para além da transmissão de mensagens. In: Semiótica da cultura e semiosfera. São Paulo: Fapesp/AnnaBlume, 2007b, pp. 57-68.

Um projeto semiótico para o estudo da cultura. In: Escola de semiótica. A experiência de Tártu-Moscou para o estudo da cultura. São Paulo: Fapesp/Ateliê Editorial, 2003, pp. 23-66.

MARX, Karl; ENGELS, Friedrich. Manifesto do Partido Comunista. In: Textos 3. São Paulo, s/d, pp. 13-20.

MERREL, Floyd. Iúri Lótman, C. S. Pierce e semiose cultural. In: Galáxia - Revista Transdisciplinar de Comunicação, Semiótica, Cultura. São Paulo: PEPG em Comunicação e Semiótica, n. 5, abril 2003, pp. 163-185.

MORENO, A. Wittgenstein através de imagens. Campinas/SP: UNICAMP, 1995.

MORTIER, Jeanne M. Pierre Teilhard de Chardin: o pensador universal. São Paulo: Cultrix, 1981.

NOTH, Winfried. Iúri Lótman: cultura e suas metáforas como semiosferas auto-referenciais. In: Semiótica da cultura e semiosfera (Irene Machado, org.). São Paulo: Fapesp/AnnaBlume, 2007, pp.81-95.

. Handbuch der Semiotk. Stuttgart: Metzler, 2000. 
PIERCE, Charles S. Semiótica. São Paulo: Perspectiva, 1987.

RISÉRIO, Antonio. Em defesa da semiodiversidade. In: Galáxia - Revista Transdisciplinar de Comunicação, Semiótica, Cultura. São Paulo: PEPG em Comunicação e Semiótica, no. 3, 2002, pp. 19-26.

SANTAELLA, Lucia. Linguagens líquidas na era da mobilidade. São Paulo: Paulus, 2007.

Paulo: Iluminuras, 2001.

Matrizes da linguagem e pensamento. Sonora Verbal Visual. São A teoria geral dos signos. In: Semiose e autogeração. São Paulo: Ática, 1995.

SLOTERDIJK, Peter. Esferas III - Espumas. Espanha: Casa Del Libro, 2004.

Esferas II - Globo. Espanha: Casa Del Libro, 1999.

Esferas I - Bolha. Espanha: Casa Del Libro, 1998.

TOROP, Peeter. Semiosfera como objeto de pesquisa na semiótica da cultura. In: Semiótica da cultura e semiosfera (Irene Machado, org.). São Paulo: Fapesp/AnnaBlume, 2007, pp.4556.

2000, 1: 5-22.

New Tartu Semiotics. In: European Journal for Semiotics Studies (2),

UEXKULL. Thure Von. A teoria do Umwelt de Jakob Von Uexküll. In: Galáxia - Revista Transdisciplinar de Comunicação, Semiótica, Cultura. São Paulo: PEPG em Comunicação e Semiótica, n. 3, 2003, pp. 19-48.

VERNADSKY, Wladimir. La Biosphère. Paris: Diderot, 1997.

VIEIRA, Jorge Albuquerque. Semiosfera e o conceito de Umwelt. In: Semiótica da cultura e semiosfera (Irene Machado, org.). São Paulo: Fapesp/AnnaBlume, 2007, pp. 99-111.

VITA, L. W. Introdução à filosofia. São Paulo: Melhoramentos, 1964.

WITTGENSTEIN, Ludwig. Investigações filosóficas. Lisboa: Calouste Gulbenkian, 1989. 
Original recebido em: 21/11/2011

Aceito para publicação em: 20/07/2013

Resumo do autor:

Dóris é doutoranda em Ciências da Comunicação pelo PPGCOM USP; Mestre em Educação pela PUC SP; Pós-graduada em: Gestão da Comunicação pela ECA-USP, Sociologia do Lazer pela UNICAMP, Administração do Lazer pela FAM e Introdução à História Geral da Arte pela Escola do MASP; Graduada em Educação Física pela EEFUSP. 